\title{
RESISTANCE OF ULMACEAE TO FEEDING BY THE ADULT ELM LEAF BEETLE (COLEOPTERA: CHRYSOMELIDAE)
}

\author{
by Fredric Miller ${ }^{1}$, Kimberly Malmquist ${ }^{2}$, and George Ware ${ }^{3}$
}

\begin{abstract}
Fifteen Ulmus and one Zelkova taxa were evaluated in no-choice and multiple-choice laboratory bioassays for their preference and suitability for the adult elm leaf beetle (ELB), Xanthogaleruca luteola (Müller). Suitability of each taxon was defined by the mean number of eggs laid per female and the mean percentage of females ovipositing in no-choice laboratory feeding studies. Preference for each taxon was defined by the percentage of leaf tissue removed in multiple-choice laboratory feeding studies. Adult females laid significantly more eggs on $U$. canescens and $U$. pumila, highly preferred hosts, and the cultivar U. 'Morton Stalwart' Commendation ${ }^{\mathrm{TM}}$, indicating their greater suitability for the ELB. Male and female longevity was similar for all taxa tested in this study, with both sexes living approximately $5 \pm 3$ days. Adult longevity was not correlated with suitability. Results from the multiple-choice feeding preference studies somewhat followed the suitability rankings in the no-choice feeding studies for the same taxa, with taxa that were less suitable in the no-choice studies being less preferred in the multiple-choice studies. The reverse is also true. As observed in this study and previous studies, preference and suitability increases when $U$. pumila is included as part of the parentage of simple complex hybrids. Of the 16 taxa evaluated in this study, $U$. canescens, $U$. pumila, and $U$. 'Morton Stalwart' Commendation appear to be more suitable for feeding and reproduction by adult ELBs, limiting their use in landscape and urban forest plantings where chronic ELB outbreaks are common. The North American and European elm taxa of $U$. alata, U. americana, and $U$. foliaceae, simple hybrids consisting of $U$. japonica and $U$. wilsoniana parentage, and $Z$. serrata appear to be less preferred and less suitable for reproduction by adult ELBs.
\end{abstract}

Key Words. Elm biotypes; elm leaf beetle; Ulmus; insect resistance; hybrid elm evaluation; Asian elms.

In the past several decades, extensive breeding and selection programs have focused on insect-resistant trees for forest and landscape uses (Morgan et al. 1978; Fu 1980; Cunningham and Dix 1983; DeHayes 1983; Heybroek 1983; Coffelt and Schultz 1993; Johnson et al.1993; Smalley and Guries 1993; Smitley and Peterson 1993; Santamour and Bentz 1995; Ware 1995; Miller et al. 1999; Miller et al.
2001). Elm breeding programs are currently being carried out on elms, with efforts concentrated on Dutch elm disease (DED) resistance (Townsend 1979; Townsend and Masters 1984; Townsend et al.1991; Santamour and Bentz 1995; Townsend et al.1995; Townsend and Douglass 2001), but more recently include resistance to the elm leaf beetle (ELB), Xanthogaleruca luteola (Müller) and other leafing insects such as the Japanese beetle (Popillia japonica Newman), gypsy moth (Lymantria dispar L.), elm leaf miner (Fenusa ulmi Sundevall), fall cankerworm [Alsophila pometaria (Harris)], and spring cankerworm [Paleacrita vernata (Peck)] (Luck and Scriven 1979; Hall 1986; Hall and Young 1986; Young and Hall 1986; Hall and Townsend 1987; Hall et al.1987; Miller and Ware 1994, 1997, 1999; Miller et al.1999; Miller 2000; Miller and Ware 2001a, 2001b, 2001c, 2001d; Miller et al. 2001; Miller and Ware 2002).

Specifically, the ELB is a common defoliator of elms (Ulmus spp.) and is a significant pest affecting urban elm trees in most parts of the United States (Wu et al.1991). It is originally from Europe and was imported into the United States in the 1830s.

Previous efforts have focused on the preference for and suitability of various elm species and their hybrids for feeding by ELB (Luck and Scriven 1979; Hall 1986; Hall and Young 1986; Young and Hall 1986; Hall and Townsend 1987; Hall et al.1987; Miller 2000; Miller and Ware 1994, 1997, 1999, 2001a, 2001b, 2001c, 2001d, 2002). In all of these studies, suitability was defined as the mean number of eggs laid per adult female beetle and mean percentage of females ovipositing in no-choice feeding studies. Preference was defined as the mean percentage of leaf tissue removed in multiple-choice feeding studies. Siberian elm (U. pumila L.) was highly preferred, while lacebark elm (U. parvifolia Jacq.) was least preferred (Miller and Ware 1994, 1997), and Hall (1986) demonstrated that U. japonica Sarg. and U. wilsoniana Schneid. were somewhat intermediate in suitability. Additionally, nearly 30 elm taxa have been found to have low to moderate suitability for the ELB (Luck and Scriven 1979; Hall et al. 1987; Miller 2000; Miller and Ware 1994, 1997, 1999, 2001a, 2001b, 2001c, 2001d, 2002).

Only three previous studies have been conducted that include the insect resistance of North American and European elm biotypes (Luck and Scriven 1979; Hall et al.1987; Miller and Ware 2002). In these studies, certain European species were found to be more suitable than North American 
or Asian species. In addition, very little is known about the ELB susceptibility of some of the more recently developed and acquired unique Asia elm taxa containing $U$. japonica, $U$. pumila, and $U$. wilsoniana parentage. The objectives of this study were to evaluate the (1) suitability of additional North American and European elm taxa, and (2) preference and suitability of unique Asian elm taxa for ELB. The experiment summarized here examines the susceptibility of 15 North American, European, and Asian elm taxa and Zelkova serrata for feeding by the adult ELB. These results provide a more comprehensive picture of the susceptibility of Ulmaceae to the ELB and provide further direction for future breeding programs for resistance to other leaf-feeding insect pests such as the Japanese beetle, elm leafminer, gypsy moth, and spring and fall cankerworms.

Ultimately, this research will provide the horticulturist, arborist, urban forester, and other green-industry members with additional shade tree selections that are less susceptible to the leaf-feeding insect pests reported here and to lethal plant pathogens. Development and use of these less susceptible and/or resistant elm taxa will aid in minimizing the need for the use of chemical control measures, thus reducing the effect of pesticides on the environment and nontarget organisms, pest resistance, and pesticide exposure to the public and applicators.

\section{MATERIALS AND METHODS}

\section{No-Choice Adult Suitability Laboratory Bioassays}

No-choice laboratory feeding assays (Miller and Ware 2001a, 2001b, 2001c, 2001d, 2002) were conducted on 2,000 second-generation (early to mid August) adult ELBs. Four North American elm taxa, six taxa of European and Asian elm parentage, five simple hybrids of $U$. americana, $U$. japonica, U. pumila and U. wilsoniana parentage, and $Z$. serrata were evaluated. Ulmus pumila is a highly preferred host of the ELB and served as the reference in all of the studies. Candidate elm biotypes and leaf sampling were identical to the study above, except that leaf samples were held in cold storage for a maximum of 2 days. Three individual trees of each Ulmus and Zelkova taxon were evaluated (Table 1).

Adult beetles emerged from field-collected third instars and pupae shipped overnight from sites in and around North Platte, Nebraska, U.S. Upon arrival, the pupae were sexually segregated and held under a photoperiod of 16:8 (L:D) h at approximately $25^{\circ} \mathrm{C}$.

One newly emerged unfed male and female were placed together in each of ten plastic Petri dishes $(10 \times 0.6 \mathrm{~cm})$ with foliage from the test elms. Petri dishes were examined daily and the foliage inspected for evidence of feeding and oviposition. Fecundity and beetle mortality were recorded. Foliage was replaced every 2 days. Beetles that died within the first 3 days were replaced with newly emerged, unfed adults to ensure that healthy beetles had an opportunity to feed on test elms. Petri dishes were placed in clear plastic bags to prevent drying of the foliage and were held under a photoperiod of $16: 8$ (L:D) h at approximately $25^{\circ} \mathrm{C}$. Condensation of water on the lid of the Petri dish indicated high relative humidity. Each of the three trees for every taxon was assayed with ten pairs of beetles. Bioassays were terminated after 21 days.

Mean number of eggs laid per female was calculated by totaling all of the eggs laid by each adult female in each individual Petri dish within a given taxon during the 21-day study. We also determined the overall percentage of females that oviposited on each biotype and the mean preovipositional period. Male and female longevity from the date that the beetles were introduced to the foliage was also determined. Adult beetles that were still alive at the end of 21 days were assigned longevities of 21 days. The measure of suitability for each taxon was defined by the mean number of eggs laid per female and the mean percentage of females ovipositing in the no-choice feeding study (Miller and Ware 1994, 1997, 1999, 2001a, 2001b, 2001c, 2001d).

\section{Multiple-Choice Laboratory Bioassay Adult Feeding Study}

A male/female pair of newly emerged, unfed, adult beetles was placed in each of ten plastic Petri dishes $(15 \times 0.6 \mathrm{~cm})$. Each adult pair served as a replicate. Into each dish was placed three circular foliage discs ( $1 \mathrm{~cm}$ in diameter) and one each of each taxon to be evaluated, evenly spaced and touching the outside perimeter of the dish. Beetles had access to all foliage sections. The Petri dishes were examined daily for 7 days. Each day, the leaf discs were removed, replaced, and evaluated for percentage of leaf tissue removed by adult feeding. New foliage sections were arranged randomly each day. Percentage of leaf area removed was estimated visually to the nearest 5\% using a defoliation template and recorded. Preference was defined using the results from the mean percentage of leaf tissue removed in the multiple-choice feeding study (Miller and Ware 1999, 2001a).

\section{Statistical Analysis}

Proportional data were arcsine square root transformed to correct for non-normality. Measures of suitability and preference, including mean eggs laid per female, percentage of females ovipositing, preovipositional period, male longevity, female longevity, and percentage of leaf tissue removed, were subjected to analysis of variance (ANOVA) using taxon as the main effect, followed by the StudentNewman-Keuls (SNK) multiple comparison test using SigmaStat for Windows (Jandel Scientific 1992). All data are presented as original means \pm SEM.

\section{RESULTS AND DISCUSSION} No-Choice Adult Suitability Laboratory Bioassays Overall, of the 16 Ulmaceae taxa evaluated for adult ELB feeding suitability and preference, the highly preferred Siberian elm (U. pumila), U. canescens, and the cultivar U. 'Morton Stalwart' Commendation ${ }^{\mathrm{TM}}\left(U\right.$. 'Morton' Accolade ${ }^{\mathrm{TM}}$ 
$\times U$. pumila $-U$. carpinifolia) were the most highly suitable and preferred by the ELB, with 48, 35, and 43 eggs laid per female, respectively $(F=78.9 ; P<0.0001)$. The remaining 13 taxa were significantly less suitable, with $<16$ eggs laid per female (Table 2). No eggs were laid on U. americana (diploid form), $U$. japonica $\times U$. wilsoniana (Arnold Arboretum selection),
U. americana 'Moline', U. wilsoniana-98, and Zelkova serrata (Table 2). The simple hybrid $U$. pumila $\times U$. americana was intermediate in suitability, with 29 eggs laid per female. In a previous study by Miller and Ware (1994), U. pumila $\times U$. americana was found to be moderately suitable ( mean $=64$ eggs laid per female and 64\% of females laying eggs).

Table 1. Ulmaceae taxa evaluated in elm leaf beetle (Xanthogaleruca luteola) no-choice and multiple-choice laboratory feeding studies.

\begin{tabular}{|c|c|}
\hline Biotype & Parentage \\
\hline \multicolumn{2}{|l|}{ Ulmus alata } \\
\hline \multicolumn{2}{|l|}{ U. americana (diploid form) } \\
\hline \multicolumn{2}{|l|}{ U. americana 'Moline' } \\
\hline \multicolumn{2}{|l|}{ U. canescens } \\
\hline \multicolumn{2}{|l|}{ U. foliaceae } \\
\hline$U$. japonica $\times U$. americana & U. japonica (50\%), U. americana (50\%) \\
\hline$U$. japonica $\times U$. pumila (columnar selection) & U. japonica (50\%), U. pumila (50\%) \\
\hline$U$. japonica $\times U$. wilsoniana (Arnold arboretum selection) & U. japonica (50\%), U. wilsoniana (50\%) \\
\hline U. japonica $\times U$. wilsoniana (single stem selection) & U. japonica (50\%), U. wilsoniana (50\%) \\
\hline U. japonica-wilsoniana $\times U$. rubra & U. japonica-wilsoniana (50\%), U. rubra (50\%) \\
\hline \multicolumn{2}{|l|}{ U. pumila (reference) } \\
\hline$U$. pumila $\times U$. americana & U. pumila (50\%), U. americana (50\%) \\
\hline \multicolumn{2}{|l|}{ U. wilsoniana-98 } \\
\hline $\begin{array}{l}\text { U. 'Morton Stalwart' Commendation }{ }^{\mathrm{TM}} \\
\text { (U. 'Morton' Accolade } \times \text { U. pumila-carpinifolia) }\end{array}$ & $\begin{array}{l}\text { U. 'Morton' Accolade }{ }^{\mathrm{TM}}(50 \%) \text {, } \\
\text { U. pumila-carpinifolia }(50 \%)\end{array}$ \\
\hline$U$. 'Morton Plainsman' Vanguard ${ }^{\mathrm{TM}} \times U$. americana (diploid form) & U. 'Morton Plainsman' Vanguard (50\%) \\
\hline & U. americana (diploid form) (50\%) \\
\hline
\end{tabular}

Zelkova serrata

Table 2. Mean \pm SEM eggs laid per female, percentage of females ovipositing, preovipositional period (POP), male longevity, and female longevity for adult elm leaf beetles (Xanthogaleruca luteola) feeding on leaves of Ulmaceae taxa.

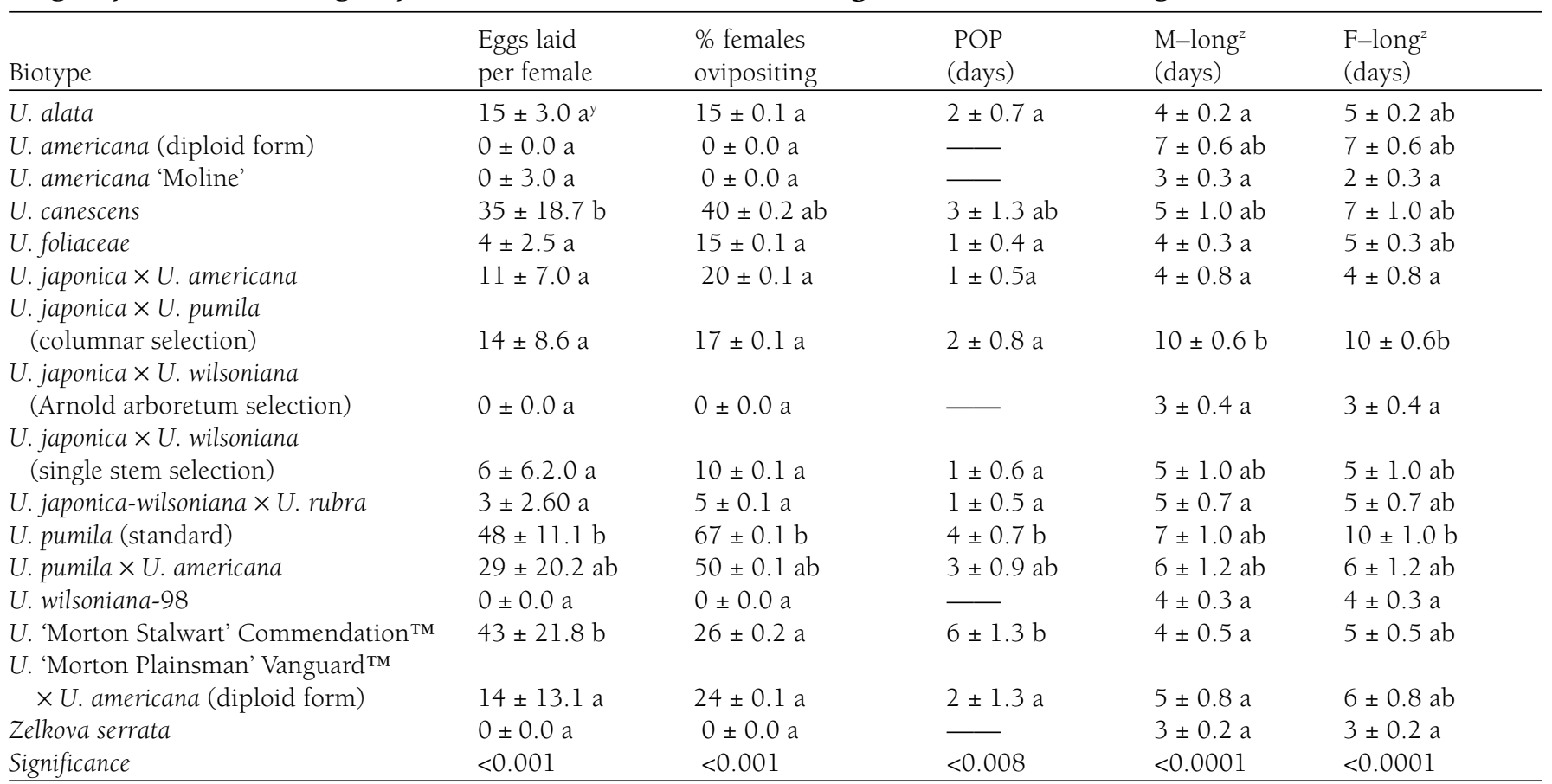

${ }^{z}$ M-long = male longevity; F-long = female longevity.

YValues within columns followed by the same letter are not significantly different $[P=0.05$; Student-Newman-Keuls (SNK) multiple comparison test $]$. 
Rankings for the percentage of females ovipositing was similar to mean eggs laid per female, with a higher percentage (26\% to $67 \%$ ) of females laying eggs on the more highly suitable elm taxa and a lower percentage $(<18 \%)$ of females laying eggs on the less suitable elm taxa $(F=77.5 ; P<$ $0.0001)(R=0.95 ; P<0.0001)$ (Table 2).

The preovipositional period (POP) was significantly longer for females feeding on U. pumila (4 days) and 'Commendation' ( 6 days) $($ mean $=5$ days $)$ as compared to the other taxa $(\mathrm{POP}=$ 3 days or less; mean $=2$ days $)(F=80.6 ; P<0.0001)$.

Male longevity (M-long) and female longevity (F-long) were similar for all taxa tested in this study, with both sexes living approximately $5 \pm 3$ days. Males and females lived significantly longer (mean $=10$ days) on $U$. japonica $\times U$. pumila (columnar form) and $U$. pumila (females only) compared to $<8$ days (mean $=5$ days) for the remaining 14 elm taxa (males, $F=66.8 ; P<$ 0.0001 and females, $F=65.8 ; P<0.0001)$.

\section{Multiple-Choice Laboratory Bioassay Adult Feeding Study}

In study \#1, U. 'Morton' Accolade $\times U$. japonica-wilsonianapumila was more highly preferred to $U$. 'Morton' Accolade and $U$. 'Morton Stalwart' Commendation (Table 3) $(F=$ 9.64; $P=0.008$ ).

In study \#2, there was no significant difference in preference between simple and complex hybrids of $U$. japonica, $U$. pumila, and $U$. rubra parentage. The effect of $U$. pumila on feeding preference was observed in study \#3, where no leaf tissue was removed from U. americana leaves, but significantly more leaf tissue was removed when beetles were presented with a choice of the simple hybrid of $U$. pumila $\times U$. americana (diploid) and the highly preferred host of $U$. pumila $(F=14.3 ; P<0.001)$. Study \#4 showed that beetles prefer the simple hybrid of $U$. japonica $\times U$. americana over either species alone $(F=15.0 ; P<0.0001)$. Results from the multiple-choice feeding preference studies were similar to the suitability rankings in the no-choice feeding studies for the same taxa. Taxa that were less suitable in the no-choice studies were less preferred in the multiplechoice studies. The reverse is also true (Tables 2 and 3).

As observed in previous studies, when U. pumila is included as part of the parentage of simple and complex hybrids, suitability increases (Miller and Ware 1994, 1997, 2001b, 2001c, 2001d). In this study, the simple hybrid $U$. pumila $\times U$. americana and the complex hybrid $U$. 'Morton Stalwart' Commendation were intermediately and highly suitable, respectively. When beetles fed only on U. americana leaves, no eggs were laid. In addition, 'Accolade' alone has shown to have low preference and suitability for larvae and adults of the ELB (Miller and Ware 1997, 2001b, 2001d).

Likewise, $U$. japonica and $U$. wilsoniana have shown to have low to moderate preference and suitability for larvae and adult ELB and, when combined to form simple hybrids, they retain low suitability as seen in this and other studies (Miller and Ware 1994, 1997, 2001b, 2001d, 2002). Of the 16 taxa evaluated in this study, $U$. canescens, $U$. pumila, and the complex hybrid $U$. 'Morton Stalwart' Commendation appear to be more suitable for feeding and reproduction by adult ELBs, thereby limiting their use in landscape and urban forest plantings where chronic ELB outbreaks are common. In this study, certain North American and European elm taxa, specifically $U$. alata, U. americana, and U. foliaceae, simple hybrids consisting of $U$. japonica and $U$. wilsoniana parentage, and $Z$. serrata appear to be less preferred and less suitable for reproduction by adult ELBs and show promise for use in future elm breeding programs.

$\begin{array}{ll}\text { Study } \# 4 & 0 \pm 0.0 \mathrm{a} \\ U . \text { americana } & 0 \pm 0.0 \mathrm{a} \\ U . \text { japonica } & 13 \pm 0.0 \mathrm{~b} \\ U . \text { japonica } \times U \text {. americana } & <0.0001 \\ \text { Significance } & \end{array}$

"For each study, values within a column within a study followed by the same letter are not significantly different $[P=0.05$; Student-Newman-Keuls (SNK) multiple comparison test $]$.

$0 \pm 0.0 \mathrm{a}$

$13 \pm 0.0 b$

$<0.0001$
$8 \pm 0.0 \mathrm{~b}$

$10 \pm 0.0 \mathrm{~b}$

$<0.001$

U. pumila

Significance 


\section{LITERATURE CITED}

Coffelt, M.A., and P.B. Schultz. 1993. Host plant suitability of the orange-striped oakworm (Lepidoptera: Saturniidae). J. Environ. Hortic. 11:182-186.

Cunningham, P.A., and M.E. Dix. 1983. Variation among Siberian elms in their susceptibility to defoliation by the spring cankerworm. Proceedings of the North Central Tree Improvement Conference, Wooster, $\mathrm{OH}$.

DeHayes, D.H. 1983. Resistance of trees to insects: A geneticist's perspective. Proceedings of the Northeastern Forest Insect Work Conference, Orono, ME.

$\mathrm{Fu}, \mathrm{Li}-\mathrm{Guo}$. 1980. Studies in the genus Ulmus in China. Northeastern Forestry Institute. Harbin, China. 40 pp.

Hall, R.W. 1986. Preference and suitability of elms for adult elm leaf beetle, Xanthogaleruca luteola (Coleoptera: Chrysomelidae). Environ. Entomol. 15:143-146.

Hall, R.W., and A.M. Townsend. 1987. Suitability of Ulmus wilsoniana, the 'urban' elm, and their hybrids for the elm leaf beetle, Xanthogaleruca luteola (Müller) (Coleoptera: Chrysomelidae). Environ. Entomol. 16:10421044.

Hall, R.W., and C.E. Young. 1986. Host suitability of three Asiatic elms to the elm leaf beetle (Xanthogaleruca luteola) (Coleoptera: Chrysomelidae). J. Environ. Hortic. 4:44-46.

Hall, R.W., A.M. Townsend, and J.H. Barger. 1987. Suitability of thirteen different host species for elm leaf beetle, Xanthogaleruca luteola (Coleoptera: Chrysomelidae). J. Environ. Hortic. 5:143-145.

Heybroek, H.M. 1983. Why bother about the elm?, pp 1-8. In Sticklen, M.B., and J.L. Sherald (Eds.). Dutch Elm Disease Research: Cellular and Molecular Approaches. Springer-Verlag, New York, NY.

Jandel Scientific. 1992. SigmaStat for Windows. San Rafael, CA. 232 pp.

Johnson, M.P., D.A. Potter, and G.S. Gilmore. 1993. Suitability of juniper cultivars for survival and growth of the bagworm. J. Environ. Hortic. 11:167-170.

Luck, R.F., and G.T. Scriven. 1979. The elm leaf beetle, Pyrrhalta luteola, in southern California: Its host preference and host impact. Environ. Entomol. 8:307-313.

Miller, F. 2000. Insect resistance of elm genotypes, pp 137154. In Dunn, C. (Ed.). The Elms: Breeding, Conservation, and Disease Management. Kluwer Academic Publishers, Boston, MA.

Miller, F., and G. Ware. 1994. Preference for and suitability of selected elms, Ulmus spp., and their hybrids for the elm leaf beetle (Pyrrhalta luteola Coleoptera: Chrysomelidae). J. Environ. Hortic. 12:231-235.

_ 1997. Preference for and suitability of Asian elm species and hybrids for the adult elm leaf beetle (Coleoptera: Chrysomelidae). J. Econ. Entomol. 90:1641-1645.
1999. Resistance of elms of the Ulmus davidiana complex to defoliation by the adult elm leaf beetle (Coleoptera: Chrysomelidae) J. Econ. Entomol. 92:1147-1150.

. 2001a. Resistance of temperate Chinese elms (Ulmus spp.) to feeding by the adult elm leaf beetle (Coleoptera: Chrysomelidae). J. Econ. Entomol. 94:162-166.

-2001b. Host suitability of Asiatic elm species and hybrids for larvae and adults of the elm leaf beetle (Coleoptera: Chrysomelidae). J. Arboric. 27:118-125.

. 2001c. Evaluation of eleven newly acquired Asian elms for their suitability to adult elm leaf beetle (Coleoptera: Chrysomelidae). J. Environ. Hortic. 19:96-99.

- 2001d. Feeding and ovipositional responses of adult elm leaf beetle (Coleoptera: Chrysomelidae) to simple and complex Asian elm hybrid selections. J. Environ. Hortic. 19:128-131.

- 2002. Suitability and feeding preference of selected North American, European, and Asian elm (Ulmus spp.) biotypes to elm leaf beetle (Coleoptera: Chrysomelidae). J. Environ. Hortic. 20(3): 158-154.

Miller, F, S. Jerdan, and G. Ware. 1999. Feeding preference of adult Japanese beetles (Coleoptera: Scarabaeidae) for Asian elm species and their hybrids. J. Econ. Entomol. 92:421-426.

Miller, F., K. Malmquist, and G. Ware. 2001. Evaluation of Asian, European, and North American elm (Ulmus spp.) biotypes to feeding by spring and fall cankerworms. J. Environ. Hortic. 19:216-221.

Morgan, D.L., G.W. Frankie, and M.J. Gaylor. 1978. Potential for developing insect-resistant plant material for use in urban environments, pp 267-293. In Koehler, C.S., and G.W. Frankie (Eds.). Perspectives in Urban Entomology. Academic Press, New York, NY.

Santamour, F.S. Jr., and S.E. Bentz. 1995. Updated elm checklist (Ulmus) cultivars for use in North America. J. Arboric. 21:122-131.

Smalley, E.B., and R.P. Guries. 1993. Breeding elms for resistance to Dutch elm disease. Annu. Rev. Phytopathol. 31:325-52.

Smitley, D.R., and N.C. Peterson. 1993. Evaluation of selected crabapple cultivars for insect resistance. J. Environ. Hortic. 11:171-175.

Townsend, A.M. 1979. Influence of specific combining ability and sex of gametes on transmission of Ceratocystis ulmi resistance in Ulmus. Phytopathology 69:643-645.

Townsend, A.M., and L.W. Douglass. 2001. Variation among American elm clones in long-term dieback, growth, and survival following Ophiostoma inoculation. J. Environ. Hortic. 19:100-103.

Townsend, A.M., and W.O. Masters. 1984. 'Homestead' elm. HortScience 19:897-898. 
Townsend, A.M., R.W. Hall, and W.O. Masters. 1995.

'Patriot' elm. J. Environ. Hortic. 13:113-115.

Townsend, A.M., L.R. Schreiber, W.O. Masters, and S.E. Bentz. 1991. 'Prospector' elm. HortScience 26:81-82.

Ware, G. 1995. Little-known elms from China: Landscape tree possibilities. J. Arboric. 21:284-288.

Wu, Z.S., S. Jamieson, and J. Kielbaso. 1991. Urban forest pest management. J. Arboric. 17:150-158.

Young, C.E., and R.W. Hall. 1986. Factors influencing suitability of elms for elm leaf beetle, Xanthogaleruca luteola (Müller) (Coleoptera: Chrysomelidae). Environ. Entomol. 15:846-849.

${ }^{1 *}$ Professor of Horticulture

Joliet Junior College

1215 Houbolt Road

Joliet, IL 60431, U.S.

(Also, Research Associate, The Morton Arboretum)

${ }^{2}$ Research Assistant

${ }^{3}$ Research Dendrologist, Emeritus

The Morton Arboretum

Lisle, IL 60532, U.S.

"Corresponding author.

Résumé. Quinze taxons d'Ulmus et un de Zelkova ont été évalués avec des bio-essais en laboratoires sans choix et à choix multiples, et ce en fonction de leur préférence et de leur convenance pour le galéruque adulte de l'orme (Xanthogaleruca luteola Müller). La convenance envers chaque taxon était définie par le nombre moyen d'œufs pondus par femelle et le pourcentage moyen de femelles effectuant une oviposition, et ce dans des études en laboratoire d'alimentation sans choix. La préférence pour chaque taxon était définie par le pourcentage de tissu foliaire retiré, et ce dans des études en laboratoire d'alimentation à choix multiples. Les femelles adultes pondaient significativement plus d'œufs sur $U$. canescens et $U$. pumila, leurs hôtes préférés, et le cultivar $U$. 'Morton Stalwart' Commendation ${ }^{\mathrm{TM}}$ était le plus convenable au galéruque. La longévité des mâles et des femelles était similaire chez tous les taxons testés dans cette étude, les deux sexes vivant approximativement $5 \pm 3$ jours. La longévité des adultes n'était pas corrélée avec la convenance. Les résultats des études à choix multiples de préférence d'alimentation suivaient en quelques sortes les rangs de convenance dans les études sans choix pour les mêmes taxons, les taxons qui étaient moins convenables dans les études sans choix étaient moins préférés dans les études à choix multiples. Linverse est aussi vrai. Tel qu'observé dans cette étude ainsi que dans des études précédentes, la préférence et la convenance augmentent lorsque U. pumila est inclus comme partie parente de simples hybrides complexes. Des 16 taxons évalués dans cette étude, $U$. canescens, U. pumila et $U$. 'Morton Stalwart' Commendation apparaissent être les plus convenables pour l'alimentation et la reproduction des galéruques adultes de l'orme, ce qui limite leur usage dans les aménagements et les plantations en forêts urbaines, là où les épidémies chroniques de galéruques sont communes. Les taxons nord américains et européens de $U$. alata, $U$. americana et $U$. foliaceae, les hybrides simples formés de parentage avec $U$. japonica et $U$. wilsoniana, et $Z$. serrata apparaissent être moins préférés et moins convenables pour la reproduction des galéruques adultes de l'orme.

Resumen. Se evaluaron quince taxa de Ulmus y una de Zelkova con bioensayos de laboratorio en cuanto a su preferencia y conveniencia para el escarabajo adulto del olmo, Xanthogaleruca luteola (Müller). La conveniencia de cada taxon fue definida por el número medio de huevos colocados por hembra y el porcentaje medio de hembras que ovipositaron en los estudios de laboratorio. La conveniencia para cada taxon fue definida por el porcentaje de tejido foliar removido en los estudios de laboratorio. Las hembras adultas ovipositaron significativamente más huevos sobre U. Canescens y U. Pumila, hospederos altamente preferidos, y el cultivar U. 'Morton Stalwart' Commendation ${ }^{\mathrm{TM}}$, indicando su mayor conveniencia para el escarabajo. La longevidad para hembras y machos fue similar para todos los taxa probados en este estudio, con los dos sexos viviendo aproximadamente $5 \pm 3$ días. La longevidad de los adultos no se correlacionó con la preferencia. Como se observó en este estudio y en trabajos previos, la preferencia y la conveniencia incrementa cuando U. Pumila es incluido como parte del parentesco de híbridos complejos. De los 16 taxa evaluados en este estudio $U$. canescens, $U$. pumila, y $U$. 'Morton Stalwart' Commendation parecen ser más convenientes para alimento y reproducción por escarabajos adultos, limitando su uso en paisajes y plantaciones forestales urbanas donde la incidencia del escarabajo es común. El taxa del olmo de Norteamérica y Europa de U. alata, U. americana, y U. Foliaceae, híbridos simples consistentes de U. Japónica, U. wilsoniana parentage, y Z. serrata parecen ser menos preferidos y menos convenientes para la reproducción por escarabajos adultos. 